\title{
EXCURSION TO DARTFORD HEATH AND JOYDEN'S WOOD.
}

\author{
Saturday, May i5Th, 1920.
}

Director:-ARThur L. LEACH, F.G.S.

Excursion Secretary:-Miss DOROTHY WOOdHEAD.

\section{(Report by the Director.)}

The party assembled at Crayford railway station at 2.30 p.m., and walked first to a new section in Thanet Sand, exposed near the trolley-line running up to the gravel pit. The chief point of interest in this section was the presence of several thin bands of light porous loam interbedded apparently with normal Thanet Sand. These loam bands ran in almost horizontally from the original sloping ground surface and died away in a few yards. Such loam bands are quite unknown in any other section of Thanet Sand and although they are here apparently interbedded with undisturbed Thanet Sand it seems most probable that appearances are deceptive and that the banding is due to. re-arrangement long after the formation of the Thanet Sand, and probably during the deposition of the adjacent Pleistocene brick-earths in the Cray valley.

The party next went up to the large pit above Wantsunt, where the gravel has many times previously been examined. The Director gave an account of the extent, thickness, rock constituents and fossils of this deposit-the High Terrace gravel of Dartford Heath. The implementiferous channel on the northern side of the pit was also examined. Detailed accounts of the Dartford Heath Gravel and of the implementiferous channcl have been given several times. (See References.)

The party now crossed the Heath to the "Chalet" for tea and afterwards walked past Leyton Cross and along Birchwood Road to the entrance to Joyden's Wood. Some time was spent here in noting the remains of a quadrangular earthwork intersected by the path through the wood, and an old discussion was again revived when some of the deneholes near Bexley were observed, and questions as to their age and purpose were raised. Some notes on these deneholes have been given in the report of the Excursion of September I9I7. The party reached Bexley in time for the 8.29 train to London. 
REFERENCES.

Igi 2. Chandler, R. H., and Leach, A. L.- " On the Dartford Heath Gravel, and on a Palæolithic Implement Factory." Proc. Geol. Assoc., vol. xxiii.

I9I4. Dewey, H., and Smith, R. A.- "The High Terrace of the Thames. Report of Excavations made on behalf of the British Museum and H.M. Geological Survey, in I9r3." Archaologia, vol. lxv., p. I87.

See also the Proceedings for Reports of Excursions to Crayford and Dartford Heath, taken by R. H. CHANDLER and A. L. Leach, in Igo7 (vol. Xx.); IgI I (vol. xxii.); I9I3 (vol. xxiv.); 1916 (vol. xxvii.); 1917 (vol. xxix.). 